\title{
PENGARUSUTAMAAN GENDER DALAM PROGRAM GERBANG HEBAT SEBAGAI STRATEGI PENGENTASAN KEMISKINAN DI KOTA SEMARANG
}

\author{
Gender Mainstreaming Integration into Poverty Alleviation Program \\ Strategy in Semarang City case.
}

\author{
Landung Esariti ${ }^{1}$, Lillah Haulah² ${ }^{2}$ S. Sunarti ${ }^{1}$
}

Diterima: 28 Maret 2018 Disetujui: 17 Agustus 2018

\begin{abstract}
Abstrak : Tujuan pengarusutamaan gender adalah memastikan bahwa akses, partisipasi, manfaat dan kontrol yang dilakukan laki laki dan perempuan pada level individu dan rumah tangga diakomodir dengan baik. Sebagai salah satu prinsip pembangunan nasional, gender wajib diintegrasikan dalam pembangunan sektoral termasuk upaya pengentasan kemiskinan di level Kota / Kabupaten. Hal inilah yang melatarbelakangi perlunya melihat apakah program Gerbang Hebat yang diinisiasi sejak April 2016 sudah berhasil menerapkan perencanaan program berbasis gender. Alasan tersebut, melatarbelakangi perumusan tujuan penelitian ini yaitu untuk menganalisis sejauh mana penerapan pengarusutamaan gender dalam strategi pengentasan kemiskinan diaplikasikan melalui indikator akses, partisipasi, manfaat dan kontrol. Berdasarkan hasil pendekatan kuantitif dalam wawancara secara terstruktur kepada 16 responden yang mewakili 12 OPD di Kota Semarang, diperoleh beberapa temuan berikut. Dalam konteks perbandingan antara tujuan Gerbang Hebat dengan tujuan pengarusutamaan gender ditemukan adanya kesesuaian. Telaah lebih dalam pada kesesuaian Gerbang Hebat sebagai suatu strategi pengentasan kemiskinan maka ditemukan adanya kekurangsesuaian yang tidak signifikan. Walaupun pada prinsipnya, pelaksanaan Gerbang Hebat telah mencakup pada variabel kunci yaitu (a) pemberian kesempatan, (b) peningkatan kapasitas, (c) jaminaan keselamatan dan (d) pemberdayaan masyarakat. Namun, perlu adanya penguatan pemahaman tentang konteks gender di level perencana program. Paling tidak, perencana program menjadi lebih peka untuk membuat variasi program agar dapat memberikan kesempatan pada kegiatan peningkatan kualitas hidup yang lebih baik, sebagai tujuan akhir semua program pengentasan kemiskinan.
\end{abstract}

Kata kunci: gender, program pengentasan kemiskinan, rumah tangga miskin

Abstract : The purpose of gender mainstreaming is to ensure that access, participation, benefits and control by men and women at the individual and household levels are well accommodated. As one of the national development principles, gender must be integrated in sectoral development including efforts to reduce poverty at the City / District level. This trigger the need to research on whether the Gerbang Hebat program initiated since April 2016 has succeeded in implementing gender-based program planning. Based on the results of the quantitative approach in structured

\footnotetext{
${ }^{1}$ Departemen Perencanaan Wilayah dan Kota, Universitas Diponegoro

${ }^{2}$ Direktorat Jenderal Tata Ruang, Kementerian Agraria dan Tata Ruang/BPN
} 
interviews with 16 respondents representing 12 government agencies in Semarang City, the following findings were obtained. There is a merit in the context of comparisons between the purpose of the Gerbang Hebat with gender mainstreaming objective. A deeper examination of the suitability of the Gerbang Hebat as a poverty reduction strategy found a less insufficiency. Although in principle, the implementation of the Gerbang Hebat has included key variables, namely (a) opportunity provision, (b) capacity building, (c) security and (d) community empowerment. However, there is a need to strengthen understanding of the gender context at the program planner level. Specifically, program planners should be more sensitive to varying programs to provide opportunities for better quality of life improvement activities, as the final objective of all poverty alleviation programs.

Keywords: gender, poverty alleviation programs, low income households

\section{PENDAHULUAN}

Sejalan dengan Instruksi Presiden No 9/2000, gender menjadi salah satu prinsip pokok pembangunan nasional di Indonesia. Hal ini menegaskan perlunya mengintegrasikan perspektif gender dalam aspek perencanaan, pelaksanaan, pemantauan dan evaluasi pembangunan (Sekretariat Negara, 2000). Dalam prosesnya sejak 2012, pengarusutamaan gender menjadi salah satu komponen wajib pengajuan rencana program pemerintah daerah. Secara spesifik, Bappenas dan Depdagri merekomendasikan bahwa tanpa adanya program berbasis gender dan anggaran responsif gender, maka dukungan finansial dari pemerintah pusat untuk pelaksanaan pembangunan di daerah tidak akan diberikan (World Bank, 2007).

Terkait dengan program pengentasan kemiskinan, PNPM Support Facility mendokumentasikan bahwa selama pelaksanaan program pengentasan kemiskinan berbasis pemberdayaan masyarakat di Indonesia sejak tahun 2000, ada beberapa permasalahan pelaksanaan program terkait dengan gender (The World Bank - PNPM Support Facility, Jakarta, 2015). Beberapa yang menjadi temuan dan hampir terjadi di seluruh wilayah PNPM adalah (a) kurangnya partisipasi perempuan dalam hal perencanaan dan evaluasi program. Perempuan tidak dilibatkan, hanya menjadi kelengkapan terpenuhinya syarat program berbasis gender. Lalu, (b) kurangnya pemahaman fasilitator terhadap kondisi budaya setempat, sehingga menghambat efektivitas proses penyerapan manfaat program oleh masyarakat. Ini termasuk di dalamnya pemahaman pembagian peran laki laki dan perempuan dalam rumah tangga, yang sangat berbeda pada sebagian besar masyarakat yang menganut paham patrialinisme dan matrialinisme seperti yang terjadi di Padang, Makassar, Jawa secara keseluruhan dan Bali(Bappenas, 2001). Selanjutnya, (c) belum diintegrasikannya strategi pengentasan kemiskinan pada aspek penting pemberdayaan, yaitu bagaimana individu dalam rumah tangga miskin mampu memiliki kontrol terhadap keputusan penting dalam penguasaan sumber daya untuk pencapaian kehidupan yang lebih baik. Misalnya bagaimana perempuan dapat bekerja di luar rumah dan juga dilibatkan dalam pengambilan keputusan di dalam lingkungan Rukun Tetangga dan Rukun Warga. Terakhir (d) pemaknaan gender yang dipahami secara terbatas pada konteks perbedaan laki-laki dan perempuan saja. Padahal perencanaan berbasis gender adalah perencanaan berbasis keadilan yang mengedepankan akomodasi kebutuhan bagi seluruh kelompok masyarakat yang dilibatkan dalam program pengentasan kemiskinan (Chant, 2013)(Urban Development Vienna., 2013)(Bappenas, 2001). Termasuk didalamnya adalah, tidak hanya laki-laki dan perempuan saja, tetapi juga anak-anak, lansia/ jompo, kelompok berkebutuhan khusus, serta kelompok marginal lainnya.

Mengapa program pengentasan kemiskinan perlu berorientasi pada perspektif gender?. Ada beberapa hal yang menjadi alasannya, seperti yang dikutip dari beberapa literatur (Swiss Agency for Development and Cooperation, 2003), (Rubin \& Bartle, 2005), 
(Kelkar, 2005), (Women and Development Unit, 2004), (Holmes \& Jones, 2010), (Moser \& Moser, 2005), (Chen et al., 2016). Pertama, kemiskinan merupakan kondisi yang dialami oleh rumahtangga yang secara sistem tidak dapat mengakses kondisi kehidupan yang lebih baik. Biasanya kondisi kemiskinan di Indonesia diukur berdasarkan 14 kriteria kemiskinan yang diadopsi dari Badan Pusat Statistik. Salah satu kriteria kemiskinan tersebut adalah hubungan antara tingkat pendidikan dengan sumber penghasilan keluarga. Faktor ini bersifat individual, kondisinya sangat beragam dan berbeda dari satu rumah tangga ke rumah tangga lain. Kondisi ini tidak pernah atau belum mendapat perhatian pemerintah saat merencanakan strategi pengentasan kemiskinan, karena program yang dibuat masih bersifat umum. Selain kondisi individu tersebut, fakta menyebutkan bahwa kepala rumah tangga miskin juga dapat berupa kepala rumah tangga wanita, yang mengalami beban lebih (triple burden of poverty). Pengalaman mengakses ke sumber daya untuk mencari penghidupan yang lebih baik, akan berbeda antara kepala rumah tangga laki laki dan perempuan(Ruddick, 1996)(Fenster, 2005)(Narayan, 2005)(Narayan, 2005). Ini yang perlu juga diperhatikan dalam perencanaan strategi pengentasan kemiskinan.

Alasan kedua adalah, dengan adanya program pengentasan kemiskinan berbasis gender akan merangsang munculnya pemberdayaan. Tujuan jangka panjang adanya kemandirian masyarakat untuk meningkatkan taraf hidupnya hanya dapat dilakukan dengan adanya pemberdayaan, bagaimana masyarakat dapat mengambil keputusan dan mengkontrol sumber daya untuk pencapaian kehidupan lebih baik tersebut (Narayan, 2005). Ini berarti mengurangi beban masyarakat terhadap dukungan finansial dan dukungan teknis dari pemerintah. Alasan ketiga adalah mempermudah program berjalan secara efektif karena jelasnya capaian program. Program berbasis gender akan memastikan partisipasi, manfaat dan dampak program menjadi lebih jelas dan terperinci karena adanya data pemilahan antara stakeholder yang dilibatkan (laki-laki, perempuan, anak-anak, orang tua, kelompok berkebutuhan khusus, dan kelompok marginal lainnya (Rodenberg, 2004)(Nato, 2004).

Artikel ini bertujuan untuk menelaah sejauh mana program Gerbang Hebat telah menerapkan pendekatan perencanaan berbasis gender dalam upaya pengentasan kemiskinan di Kota Semarang. Ini menjadi penting untuk dilakukan karena perencanaan berbasis gender menjamin perencanaan berbasis keadilan dan merangsang tumbuhnya pemberdayaan masyarakat. Artikel ini terdiri dari empat sub pokok pembahasan. Pembahasan pertama menjelaskan mengenai latar belakang dilakukannya penelitian yang melandasi artikel ini. Pada bagian kedua didiskusikan telaah literatur, metode dan data yang digunakan dalam analisis. Bagian ketiga menguraikan hasil pembahasan kesesuaian perencanaan program Gerbang Hebat dengan prinsip-prinsip pengarusutamaan gender. Bagian kelima berisi kesimpulan dan rekomendasi faktor penentu integrasi pengarusutamaan gender pada Gerbang Hebat sebagai strategi pengentasan kemiskinan Kota Semarang.

\section{METODE}

Penelitian ini menggunakan pendekatan kuantitatif dengan perumusan variabel kunci diolah dari diskusi literatur. Selanjutnya variabel-variabel tersebut menjadi panduan wawancara yang dilakukan terhadap beberapa OPD (Organisasi Perangkat Daerah) terkait, yakni (1) BAPPEDA, (2) Dinas Perumahan dan Kawasan Permukiman, (3) Dinas Perindustrian, (4) Dinas Perikanan, (5) Dinas Sosial, (6) Dinas Pemberdayaan Perempuan dan Perlindungan Anak, (7) Dinas Pendidikan, (8) Dinas Pengendalian Penduduk dan Keluarga Berencana, (9) Dinas Tenaga Kerja, (10) Dinas Kesehatan, (11) Dinas Koperasi dan Usaha Mikro, dan (12) Dinas Pertanian. Total jumlah responden adalah 16 dan wawancara dilakukan dengan metode wawancara terstruktur terhadap kesiapan pelaksanaan program Gerbang Hebat (Lillah Haulah, 2018). 
Dalam konsep pengentasan kemiskinan, seperti yang direkomendasikan oleh (World Bank, 2007), maka (a) akses ke sumber daya, (b) pengembangan kemampuan, (c). kerentanan dan (d) kesetaraan gender harus menjadi prioritas dalam perumusan strategi nasional untuk mengurangi tingkat kemiskinan (Kelkar, 2005). Penelitian ini menitikberatkan pada aspek ke empat tentang kesetaraan gender, yaitu memahami bahwa konsep pengarustamaan gender penting untuk menjadi pendekatan perencanaan yang harus terintegrasi pada strategi sektoral upaya pengentasan kemiskinan.

'Gender mainstreaming (pengarusutamaan gender) adalah suatu strategi yang dibangun untuk mengintegrasikan permasalahan perempuan dan laki-laki ke dalam proses perencanaan, pelaksanaan, pemantauan dan evaluasi atas seluruh kebijakan program proyek dan kegiatan pembangunan nasional di seluruh bidang dan sektor pembangunan' (Bappenas, 2001).

Sampai dengan saat ini, pendekatan ekonomi politik yang dilakukan pada programprogram pengentasan kemiskinan lebih berfokus pada 3 aspek perlindungan sosial (Holmes \& Jones, 2010), yaitu; Bagaimana peluang atau hambatan dari instansi kunci dalam kebijakan perlindungan sosial dan pengembangan program, Memfasilitasi partisipasi dan keterwakilan kepentingan para pelaku utama (misalnya elit politik, birokrasi, donor, dan masyarakat sipil) dan bagaimana ini dimediasi melalui berbagai tingkat kapasitas dan pengaruh; Konsepsi penyebab kemiskinan oleh beberapa perwakilan baik dari pemerintah, masyarakat, swasta dan organisasi non-pemerintah yang belum berorientasi pada dukungan untuk mengatasi kerentanan, termasuk kerentanan khusus gender.

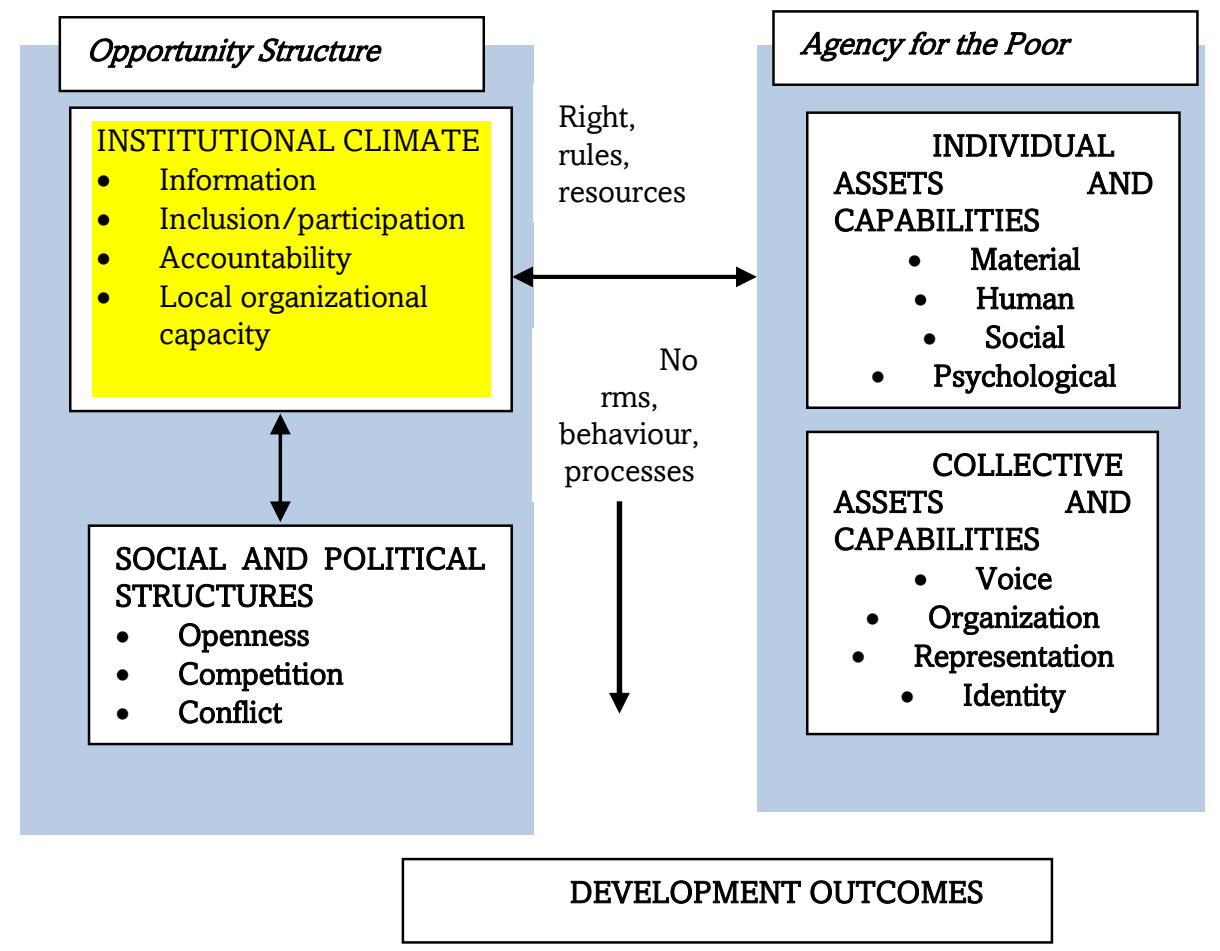

Sumber: Narayan (2002) \& Narayan (2005)

Gambar 1. Kerangka Analisis Hubungan Antara Pengentasan Kemiskinan dan Pemberdayaan Berbasis Gender 
Tujuan pengarusutamaan gender adalah memastikan apakah perempuan dan laki-laki memperoleh akses yang sama kepada sumberdaya pembangunan, berpartisipasi yang sama dalam proses pembangunan, termasuk proses pengambilan keputusan, mempunyai kontrol yang sama atas sumberdaya pembangunan, dan memperoleh manfaat yang sama dari hasil pembangunan (Bappenas, 2001).

Prinsip ini diterapkan dalam beberapa indikator perencanaan program, yang lebih beorientasi pada penciptaan tata kelola pemerintahan yang baik, seperti yang ada dalam Diagram 1 di atas pada kotak Institutional Climate. Prinsip dasar antara gender mainstreaming (GM) akan sangat berkorelasi dengan prinsip good governance (GG) yang diterjemahkan menjadi Institutional Climate. Sebagai contoh misalnya prinsip akses pada GM akan berkorelasi pada prinsip information pada GG. Artinya perlu adanya pemberian akses seluas-luasnya pada masyarakat untuk mengetahui informasi yang terkait dengan program Gerbang Hebat. Dapat berupa informasi tentang stakeholder yang dilibatkan, jenis dukungan teknis yang diberikan, jumlah dukungan finansial yang tersedia serta mekanisme penyampaian evaluasi seperti apa yang sebaiknya dilakukan. Demikian seterusnya pada korelasi 3 prinsip lain. Maka, prinsip inclusion dalam GG akan berkorelasi dengan pronsip partisipasi dalam GM, prinsip accountability GG akan berkorelasi dengan prinsip kontrol dalam GM. Yang terakhir, prinsip local organizational capacity dalam GG akan berorientasi pada prinsip manfaat pada GM.

"Gender-responsive poverty reduction programming is the analysis, design, implementation, monitoring, managing and evaluation of population and development programmes that focuses on poverty reduction and development promotion from a gender perspective" (Nato, 2004).

Sehingga, sebagai kesimpulannya, perumusan strategi pengentasan kemiskinan berbasis gender, seharusnya mencakup 4 aspek seperti berikut ini (Nato, 2004):

Dimensi kesempatan, perencanaan program pengentasan kemiskinan mengandung arti pemberian kesempatan yang sama terhadap akses lapangan pekerjaan, sumber daya produktif yang menghasilkan, serta terbukanya kesempatan untuk berperan dalam urusan rumah tangga dan lingkungan tempat tinggalnya.

Dimensi kapasitas, aspek ini menjamin terpenuhinya akses rumahtangga miskin terhadap pemenuhan sarana dan prasarana dasar. Indikator yang dapat dilihat adalah pada angka harapan hidup, tingkat buta huruf, tingkat pendudukan dan pemenuhan gizi keluarga.

Dimensi jaminan keamanan, tujuan aspek ini adalah mengurangi kerentanan (vulnerability) rumah tangga miskin pada resiko ekonomi, kekerasan dalam rumah tangga dan kebencanaan. Sehingga desain program seharusnya dapat membantu rumah tangga miskin untuk mempersiapkan dan mengelola resiko dengan tepat.

Dimensi pemberdayaan, ini berarti program dapat membuka kesempatan individu (baik laki-laki maupun perempuan) untuk dapat mengambil keputusan dalam rumah tangga dan lingkungan. Lebih jauh lagi, diharapkan individu tersebut dalam mengontrol pengelolaan sumber daya yang ada di dalam keluarga dan lingkungan tempat tinggalnya.

Terkait konteks integrasi perencanaan berbasis gender seperti yang diuraikan, maka dapat disimpulkan variabel kunci yang menjadi pedoman pengumpulan data dan sebagai panduan wawancara terhadap responden adalah sebagai berikut. 
Tabel 1. Variabel Penelitian

\begin{tabular}{|c|c|c|}
\hline No & Aspek & $\begin{array}{ll}\text { Variabel } \\
\end{array}$ \\
\hline 1 & Akses & $\begin{array}{l}\text { Bagaimana Akses laki laki dan perempuan terhadap informasi program Gerdu } \\
\text { Kempling dan Gerbang Hebat? } \\
\text { Siapa saja yang dapat (eligible) menjadi penerima program? } \\
\text { - Apakah dilakukan sosialisasi sebelum program dilaksanakan? } \\
\text { - Bagaimanakah bentuk sosialisasi yang dilakukan?, serta } \\
\text { - } \quad \text { Berapa lama sosialisasi dilakukan? }\end{array}$ \\
\hline 2 & Inklusi & $\begin{array}{l}\text { Apakah ada kesempatan yang sama untuk dipilih sebagai penerima program } \\
\text { bantuan? } \\
\text { Bagaimana cara menentukan target penerima bantuan? }\end{array}$ \\
\hline 3 & Partisipasi & $\begin{array}{l}\text { Bagaimana keterlibatan laki laki dan perempuan terhadap informasi Gerbang } \\
\text { Hebat? } \\
\text { Bagaimana pembagian peran antar stakeholder dalam program Gerbang Hebat? }\end{array}$ \\
\hline 4 & Akuntabilitas & $\begin{array}{l}\text { Sejauh mana informasi tentang mekanisme pengawasan dapat dilakukan? } \\
\text { Bagaimana dengan ketersediaan dukungan finansial terhadap Gerbang Hebat? } \\
\text { Apakah ada dukungan teknis terhadap program Gerbang Hebat? Misalnya } \\
\text { bantuan atau pendampingan saat program dilaksanakan. }\end{array}$ \\
\hline 5 & Kontrol & $\begin{array}{l}\text { Siapa saja yang dapat melakukan kegiatan pengawasan, monitoring dan } \\
\text { evaluasi? } \\
\text { Apakah program sudah direncanakan untuk mencakup semua sektor yang } \\
\text { terkait dengan penyediaan sarana dan prasarana umum? } \\
\text { Bagaimana jangkauan program terkait dengan penyediaan sarana dan } \\
\text { prasarana umum? }\end{array}$ \\
\hline 6 & $\begin{array}{l}\text { Pengembangan } \\
\text { Kapasitas Lokal }\end{array}$ & $\begin{array}{l}\text { Apakah diberikan pelatihan yang relevan terkait dengan salah satu cluster yang } \\
\text { direncanakan dalam program Gerbang Hebat? } \\
\text { Bagaimana bentuk tugas dan kewajiban masyarakat dalam program Gerbang } \\
\text { Hebat? } \\
\text { Apakah ada aspek dalam program yang terkait dengan manajemen resiko? }\end{array}$ \\
\hline
\end{tabular}

Sumber: Analisis Peneliti, 2018

\section{HASIL DAN PEMBAHASAN}

\section{Karakteristik Program Gerbang Hebat dalam Menerapkan Prinsip Pengarusutamaan Gender}

Program Gerbang Hebat merupakan program yang dirilis oleh Pemerintah Kota Semarang pada bulan April 2016. Program tersebut dibentuk dengan tujuan untuk mengentaskan kemiskinan di Kota Semarang dengan mengoptimalkan seluruh potensi yang ada serta dengan mewujudkan keterpaduan program dan kegiatan Pemerintah Kota Semarang dengan seluruh stakeholder (Pemerintah Kota Semarang, 2017). Program Gerbang Hebat merupakan satu program besar yang melibatkan 12 OPD (Organisasi Perangkat Daerah) dan setiap OPD tersebut memiliki program-program pengentasan kemiskinan tersendiri yang sesuai dengan tugas dan fungsi pokoknya. Pelibatan OPD yang cukup banyak tersebut dilakukan agar pengentasan kemiskinan di Kota Semarang dapat menyentuh berbagai sektor sehingga memerlukan keterlibatan berbagi pihak. Adapun program-program dalam Gerbang Hebat diuraikan berdasarkan empat klaster yakni sebagai berikut (Lillah Haulah, 2018).

(1) Klaster berbasis bantuan sosial, meliputi program santunan kematian, E-Warong Program Keluarga Harapan (PKH), RTLH (Rumah Tidak Layak Huni), UHC (Universal Health Coverage), dan pembagian alat kontrasepsi gratis;

(2) Klaster berbasis pemberdayaan masyarakat, meliputi program Kampung Tematik, pelatihan, WUB (Wirausaha Baru), program peran serta dan kesetaraan gender dalam pembangunan, dan KUBE (Kelompok Usaha Bersama) PKH;

(3) Klaster berbasis fasilitasi UMKM dan mikro, meliputi program fasilitasi IKM (Industri Kecil Menengah), pengembangan sarana dan prasaranan tangkap, dan program peningkatan hasil; dan 
(4) Klaster berbasis perluasan program prorakyat, meliputi program beasiswa siswa miskin, Kredit Wibawa (Wirausaha Bangkit Jadi Jawara), RDRM (Rumah Duka Revolusi Mental), dan program pengawasan pengendalian sumber daya perikanan.

Secara umum, dapat dilihat bahwa Program Gerbang Hebat berupaya menyentuh beragam sektor, baik ekonomi, kesehatan, dan pendidikan. Setiap program di dalam Gerbang Hebat dijalankan tidak secara serentak atau bersamaan, namun menyesuaikan kebutuhan OPD dan kebutuhan masyarakat yang dituju. Dalam kata lain, masing-masing OPD bergerak secara mandiri dalam pelaksanaannya di lapangan sesuai kebutuhan yang ada. Adapun analisis program Gerbang Hebat berdasarkan variabel kunci dalam konteks integrasi perencanaan berbasis gender diuraikan sebagai berikut.

Tabel 2. Uraian Variabel Kunci

\begin{tabular}{|c|c|c|}
\hline No & Aspek & Keterangan \\
\hline 1 & Akses & $\begin{array}{l}\text { Setiap orang, baik laki-laki maupun perempuan, memiliki akses informasi yang } \\
\text { sama terhadap program Gerbang Hebat melalui brosur atau leaflet, internet, } \\
\text { maupun sosialisasi langsung } \\
\text { Hampir semua program dalam Gerbang Hebat menargetkan penerima program } \\
\text { merupakan masyarakat kurang mampu. Adapun program yang dapat diterima } \\
\text { oleh masyarakat dari berbagai kalangan yaitu UHC (Universal Health Coverage), } \\
\text { Kredit Wibawa (Wirausaha Bangkit Jadi Jawara), RDRM (Rumah Duka Revolusi } \\
\text { Mental), dan WUB (Wirausaha Baru) } \\
\text { Sosialisasi dilakukan sebelum pelaksanaan program dengan berbagai bentuk, } \\
\text { meliputi media kertas (brosur atau leaflet), media online (internet), dan } \\
\text { sosialisasi secara langsung baik dilakukan oleh pihak OPD secara langsung } \\
\text { maupun dilakukan oleh pihak kecamatan atau kelurahan. Adapun lama } \\
\text { sosialisasi tidak tentu karena melihat kebutuhan yang ada di lapangan serta } \\
\text { kemampuan OPD terkait. Biasanya sosialisasi dilakukan dalam hitungan bulan } \\
\text { karena harus mencakup seluruh kecamatan di Kota Semarang }\end{array}$ \\
\hline 2 & Inklusi & $\begin{array}{l}\text { Setiap masyarakat kurang mampu di Kota Semarang memiliki kesempatan yang } \\
\text { sama untuk menerima bantuan program. Kecuali untuk program PKH (Program } \\
\text { Keluarga Harapan), target penerima sudah ditentukan dari pihak Kementerian } \\
\text { Sosial sehingga peluang sebagai penerima bantuan tidak bisa diajukan begitu } \\
\text { saja. Kementerian Sosial sudah memiliki kriteria tersendiri dalam menentukan } \\
\text { penerima bantuan program } \\
\text { OPD biasanya memiliki syarat tertentu bagi masyarakat yang ingin menjadi } \\
\text { penerima bantuan. Jadi, masyarakat yang merasa membutuhkan bantuan harus } \\
\text { memenuhi syarat tersebut agar dapat diproses lebih lanjut. Secara umum, hal } \\
\text { yang dipertimbangkan yaitu KTP dan KK Kota Semarang, penghasilan tiap } \\
\text { bulan, dan KIM (Kartu Identitas Miskin) untuk program bantuan masyarakat } \\
\text { miskin }\end{array}$ \\
\hline 3 & Partisipasi & $\begin{array}{l}\text { Tidak ada desain khusus yang membedakan partisipasi, respon dan pengalaman } \\
\text { antara laki-laki dan perempuan sebagai pelaku utama implementasi program } \\
\text { Gerbang Hebat per klaster. } \\
\text { Program Gerbang Hebat melibatkan } 12 \text { OPD dengan program-program yang } \\
\text { menyesuaikan tugas dan fungsi pokok setiap OPD tersebut. Sejauh ini, program } \\
\text { Gerbang Hebat belum memiliki keterikatan pasti dengan swasta atau lembaga } \\
\text { lain dalam mengentaskan kemiskinan di Kota Semarang. Adapun peran } \\
\text { masyarakat hanya dilibatkan sebagai penerima manfaat program saja. }\end{array}$ \\
\hline 4 & Akuntabilitas & $\begin{array}{l}\text { Mekanisme pengawasan program Gerbang Hebat sejauh ini dilakukan dengan } \\
\text { adanya rapat koordinasi yang rutin dilakukan dua kali dalam satu tahun. Rapat } \\
\text { Koordinasi tersebut masih dalam lingkup pemerintah saja, yakni dipimpin oleh } \\
\text { Bapak Walikota dan dihadiri oleh semua OPD untuk kemudian memaparkan } \\
\text { setiap program yang dilaksanakan } \\
\text { Program Gerbang Hebat memiliki dukungan finansial yang bersumber dari } \\
\text { APBD Kota, APBD Provinsi, APBN, dan beberapa didukung oleh adanya CSR } \\
\text { yakni program Kampung Tematik dan RTLH (Rumah Tidak Layak Huni) } \\
\text { Kegiatan pendampingan di tingkat lokal kota Semarang belum dilakukan. Pada } \\
\text { kegiatan PKH, ditemukan ada fasilitator tapi program ini merupakan diinisiasi } \\
\text { dari pemerintah nasional, bukan dari Pemerintah Kota Semarang. Sehingga sifat }\end{array}$ \\
\hline
\end{tabular}




\begin{tabular}{|c|c|c|}
\hline No & Aspek & Keterangan \\
\hline 5 & Kontrol & $\begin{array}{l}\text { pendampingan menyesuiakan dengan besar kecilnya prioritas kegiatan PKH } \\
\text { dalam skala nasional. } \\
\text { Kegiatan pengawasan, monitoring dan evaluasi program Gerbang Hebat } \\
\text { dilakukan oleh Tim Koordinasi Pengentasan Kemiskinan Daerah (TKPKD) Kota } \\
\text { Semarang } \\
\text { Program Gerbang Hebat lebih terfokus pada pengembangan kualitas hidup tiap } \\
\text { individu masyarakat, sehingga sektor yang menjadi acuan lebih kepada } \\
\text { pendidikan, kesehatan, dan ekonomi masing-masing individu. Sejauh ini } \\
\text { penyediaan sarana dan prasarana umum pada program Gerbang Hebat masih } \\
\text { terbatas, mungkin hanya ada pada program Kampung Tematik saja } \\
\text { Jangkauan program terkait dengan penyediaan sarana dan prasarana umum } \\
\text { terbatas pada program Kampung Tematik, dan biasanya hanya terbatas pada } \\
\text { jaringan jalan }\end{array}$ \\
\hline 6 & $\begin{array}{l}\text { Pengembangan } \\
\text { Kapasitas Lokal }\end{array}$ & $\begin{array}{l}\text { Program Gerbang Hebat memiliki program-program pelatihan yang cukup sering } \\
\text { diadakan yang pada pelaksanaannya dilakukan oleh kelurahan terkait untuk } \\
\text { memudahkan koordinasi dengan warga setempat. Pelatihan tersebut cukup } \\
\text { beragam, salah satunya pelatihan memasak, otomotif, dan menjahit. Selain } \\
\text { pelatihan, Gerbang Hebat juga mendukung masyarakat yang sudah memiliki } \\
\text { usaha dengan program Kredit Wibawa (Wirausaha Bangkit Jadi Jawara) dan } \\
\text { KUBE (Kelompok Usaha Bersama). Kedua program tersebut berupaya } \\
\text { mendorong pengembangan usaha yang sudah dimiliki masyarakat dengan } \\
\text { memberikan dukungan finansial } \\
\text { Tidak ada tugas dan kewajiban tertentu bagi masyarakat dalam program } \\
\text { Gerbang Hebat. Namun memang pemerintah mengharapkan partisipasi aktif dari } \\
\text { masyarakat dalam kegiatan dan program Gerbang Hebat yang sedang } \\
\text { dilaksanakan, baik sekedar mengikuti sosialisasi maupun ikut menggunakan } \\
\text { program yang telah disediakan. Adapun masyarakat yang terlibat dalam } \\
\text { program Kredit Wibawa (Wirausaha Bangkit Jadi Jawara) dan KUBE (Kelompok } \\
\text { Usaha Bersama) memiliki tugas dan kewajiban untuk giat mengembangkan } \\
\text { usahanya agar dapat memberikan pengembalian modal kepada pemerintah } \\
\text { secara tepat waktu. Adapun tugas masyarakat sebagai penerima program PKH } \\
\text { (Program Keluarga Harapan) memiliki tanggung jawab untuk ikut rutin } \\
\text { mengikuti perkumpulan setiap bulannya dan wajib memberikan laporan terkait } \\
\text { penggunaan uang yang diterima } \\
\text { Gerbang Hebat memiliki program yang terkait manajemen resiko yakni program } \\
\text { Rumah Duka Revolusi Mental (RDRM) dan program peran serta dan kesetaraan } \\
\text { gender dalam pembangunan. Kedua program tersebut terfokus pada perempuan. } \\
\text { Pada RDRM, program tersebut bertujuan untuk menampung dan membantu } \\
\text { wanita yang mengalami kekerasan dalam rumah tangga. Program tersebut } \\
\text { kemudian memberikan dukungan baik secara hukum maupun psikologi untuk } \\
\text { membantu perempuan yang menjadi korban. Adapun program peran serta dan } \\
\text { kesetaraan gender dalam pembangunan merupakan program pelatihan dan } \\
\text { pengembangan bagi kepala keluarga perempuan (single parent) dan perempuan } \\
\text { rawan ekonomi. Program tersebut memberikan dukungan dengan pelatihan atau } \\
\text { yang sifatnya pemberdayaan untuk memberikan bekal kemampuan bagi kepala } \\
\text { keluarga perempuan dan perempuan rawan ekonomi }\end{array}$ \\
\hline
\end{tabular}

Sumber: Analisis Peneliti, 2018

Uraian dalam tabel menegaskan bahwa dalam desain program gerbang Hebat, strategi pengentasan kemiskinan dilakukan melalui pendekatan peningkatan aspek kehidupan yang langsung peningkatan taraf hidup. Seperti misalnya,peningkatan pendapatan keluarga, melatih ketrampilan untuk membuka peluang wirausaha, dan membuka kesempatan bagi kelompok laki laki dan perempuan agar memperoleh akses yang sama dalam program. Selain itu sudah diintegrasikan konsep kerentanan dalam desain program khusus pada kegiatan Rumah Duka Revolusi Mental dan program kesetaraan gender. Ini mengarah pada upaya program Gerbang Hebat mengintegrasikan isu gender dalam konsep perencanaan berbasis keadilan. Yaitu bagaimana mengakomodir kebutuhan spesifik dari kelompok masyarakat yang ada. 


\section{Kesesuaian Tujuan Gerbang Hebat dengan Tujuan Pengarusutamaan Gender}

Program Gerbang Hebat merupakan program Pemerintah Kota Semarang yang berupaya untuk mengentaskan kemiskinan di Kota Semarang. Program tersebut juga sebagai upaya untuk mencapai target Pemerintah Kota Semarang untuk menurunkan angka kemiskinan sebesar 2\% pertahun dari tahun 2016 sampai dengan tahun 2021 (Wahyu, 2016). Dengan demikian, pembentukan program Gerbang Hebat perlu direncanakan dan dilaksanakan dengan baik agar memperoleh hasil yang diharapkan. Adapun pembentukan program Gerbang Hebat memiliki tiga tujuan utama (Pemerintah Kota Semarang, 2018) yakni sebagai berikut.

- Guna mengoptimalkan seluruh potensi yang ada di Kota Semarang dalam percepatan penanggulangan kemiskinan sehingga tujuan dan sasaran program penanggulangan kemiskinan dapat tercapai secara efisien dan efektif

- Mewujudkan keterpaduan program dan kegiatan Pemerintah Kota Semarang dengan seluruh stakeholder khususnya dalam penanggulangan kemiskinan di Kota Semarang

- Sebagai strategi percepatan penanggulangan kemiskinan di Kota Semarang dengan mensinergikan program pemerintah kota dengan stakeholder yang ada yaitu PTN/PTS, LSM, Perbankan, BUMN, tokoh masyarakat, dan para konglomerat/pengusaha

Secara garis besar, tiga tujuan utama tersebut berupaya untuk mewujudkan program Gerbang Hebat yang mengoptimalkan seluruh potensi yang ada dengan melibatkan berbagai stakeholder agar penanggulangan kemiskinan dapat dilakukan dengan efisien dan efektif. Tujuan tersebut dapat dicapai jika setiap pemangku kepentingan memiliki komitmen kuat untuk mewujudkannya. Hal tersebut sejalan dengan pernyataan (Gopal \& Malek, 2015) bahwa program pengentasan kemiskinan perlu melibatkan semua pemangku kepentingan untuk saling berkoordinasi agar mencapai keberhasilan. Selain itu, perancangan dan implementasi program pengentasan kemiskinan memerlukan pedoman yang jelas, koordinasi antar-departemen pemerintah, partisipasi atau keterlibatan masyarakat, dan peran aktivis atau kader lokal (Suryahadi, Yumna, Raya, \& Marbun, 2010). Adapun pada pembahasan ini, perwujudan tujuan program Gerbang Hebat dianalisis dengan mengacu pada tujuan pengarusutamaan gender yakni akses, partisipasi, manfaat, dan kontrol.

Bappenas, (2001) menyatakan bahwa tujuan pengarusutamaan gender salah satunya yaitu memastikan perempuan dan laki-laki memperoleh akses yang sama kepada sumberdaya pembangunan. Hal tersebut sejalan dengan program Gerbang Hebat yang memberikan akses yang sama pada perempuan dan laki-laki dalam mengikuti program atau kegiatan yang dilakukan. Fakta di lapangan menunjukkan bahwa hampir semua program dalam Gerbang Hebat tidak membedakan untuk laki-laki dan perempuan. Hanya saja, ada satu program yakni program peran serta dan kesetaraan gender dalam pembangunan yang memberikan fokus lebih kepada kepala keluarga perempuan. Program tersebut berupa program pelatihan dan pengembangan bagi kepala keluarga perempuan (single parent) dan perempuan rawan ekonomi. Program tersebut berupa pelatihan untuk memberikan bekal kemampuan bagi kepala keluarga perempuan dan perempuan rawan ekonomi. Program tersebut memberikan akses kepada kepala keluarga perempuan untuk berkembang dan maju sebagai single parent yang lebih rentan akan masalah perekonomian.

Salah satu tujuan pengarusutamaan gender yaitu memastikan laki-laki dan perempuan berpartisipasi yang sama dalam proses pembangunan, termasuk proses pengambilan keputusan. Hal tersebut sejalan dengan pernyataan terkait implementasi program pengentasan kemiskinan yang menitikberatkan pada peran stakeholder lokal 
(Suryahadi et al., 2010). Hasil kegiatan lapangan menunjukkan bahwa program Gerbang Hebat berusaha mendorong partisipasi dari seluruh masyarakat, tanpa membedakan perempuan dan laki-laki. Namun, partisipasi tersebut masih terbatas hanya berupa kehadiran masyarakat saat sosialisasi saja, belum sampai kepada tahap pengambilan keputusan. Adapun partisipasi masyarakat dalam sosialisasi selalu terbuka untuk siapa saja, baik sosialisasi yang diadakan oleh OPD secara langsung, maupun sosialisasi melalui pihak kecamatan, kelurahan, dan PKK.

Program Gerbang Hebat sejauh ini belum memberikan kesempatan pada masyarakat luas untuk mengontrol pelaksanaan program. Pengawasan dan kontrol pelaksanaan program Gerbang Hebat masih terfokus pada lingkup pemerintahan saja, terutama OPD di level pemerintah Kota. Perangkat desa setempat sampai ketingkat Ketua RT / RW dan penduduk yang berada di lokasi target kegiatan ataupun penduduk yang mendapatkan bantuan terkait program per klaster belum dilibatkan sama sekali.

Dari observasi di lapangan, dapat disampaikan bahwa menunjukkan bahwa program Gerbang Hebat berupaya memberikan manfaat yang sama kepada seluruh masyarakat, terutama masyarakat miskin. Upaya tersebut dilihat dari persyaratan administrasi yang tidak membatasi antara laki-laki dan perempuan serta tidak menetapkan persyaratan administrasi yang sulit. Sejauh ini, persyaratan administrasi yang perlu disiapkan masyarakat untuk menerima manfaat program hanya meliputi KTP dan KK Kota Semarang serta Kartu Indonesia Miskin. Hal tersebut menunjukkan bahwa pemerintah mengusahakan agar masyarakat mudah mengikuti program atau kegiatan yang dilakukan sehingga manfaat program dapat dirasakan oleh masyarakat tanpa melalui prosedur yang birokratis.

Secara keseluruhan, uraian di atas menunjukkan bahwa sebagian besar pelaksanaan program Gerbang Hebat sejalan dengan tujuan pengarusutamaan gender. Dari semua segi, baik segi akses, partisipasi, kontrol, dan manfaat, memberikan gambaran bahwa program Gerbang Hebat berusaha memberikan kesempatan yang sama untuk masyarakat luas, baik laki-laki dan perempuan. Hanya saja, kategori partisipasi dan kontrol masih sangat terbatas dalam melibatkan masyarakat secara aktif. Yakni partisipasi belum sampai pada tahap pengambilan keputusan dan kontrol pada pelaksanakaan program belum melibatkan masyarakat luas dengan aktif. Selain itu, manfaat program belum sepenuhnya dapat dirasakan oleh seluruh lapisan masyarakat (community group), misal adanya program khusus untuk kaum berkebutuhan khusus (handicapped), orang tua / jompo dan kelompok marginal lainnya.

\section{Kesesuaian Prinsip Program Gerbang Hebat sebagai Strategi Pengentasan Kemiskinan Berbasis Gender}

Program Gerbang Hebat merupakan program pengentasan kemiskinan yang bersifat top-down sehingga pihak yang berperan dalam perencanaan dan pelaksanaan program yaitu Pemerintah Kota Semarang, meliputi OPD-OPD terkait. Strategi perencanaan yang dilakukan masih mengacu pada kebijakan pemerintah, tanpa melibatkan masyarakat secara aktif dalam perencanaan program. Dengan demikian, program Gerbang Hebat sebagai program pengentasan kemiskinan perlu membangun kapasitas kelembagaan dan memperkuat tata pemerintahan yang baik untuk mewujudkan konsep pembangunan berkelanjutan yang merata (Porter \& Bank, 2003). Di sisi lain, perumusan strategi pengentasan kemiskinan berbasis gender mempertimbangkan empat dimensi, yaitu kesempatan, kapasitas, jaminan keamanan, dan pemberdayaan masyarakat (Nato, 2004). Pada pembahasan ini, diuraikan prinsip program Gerbang Hebat berdasarkan strategi pengentasan kemiskinan berbasis gender.

Dimensi Kesempatan, program dan kegiatan dalam Gerbang Hebat memberikan kesempatan yang sama bagi seluruh kalangan masyarakat, terutama masyarakat miskin. 
Baik kesempatan dari segi partisipasi maupun pada pelaksanaan programnya. Program Gerbang Hebat tidak menitikberatkan pada perempuan ataupun laki-laki, maupun kelompok atau kalangan masyarakat tertentu, dalam pelaksanaan programnya. Adapun program terkait akses terhadap lapangan pekerjaan bersifat sama, karena semua orang memiliki kesempatan yang sama besar. Menurut (Narayan, 2005), dimensi kesempatan adalah upaya pemerintah untuk membuka peluang kepada individu dan rumah tangga miskin untuk dapat meningkatkan kualitas hidupnya sebagai tujuan strategi pengentasan kemiskinan. Akhirnya, kesempatan akan memberikan kesempatan pada perubahan ke kondisi kehidupan yang lebih baik.

Dimensi Kapasitas, sejalan dengan pernyataan (Narayan, 2005) di atas, (Nussbaum, 2011) menyebutkan pentingnya kapasitas sebagai tolok ukur adanya kemampuan individu dan rumah tangga miskin untuk mampu berubah dan melakukan kegiatan konstruktif dalam perbaikan kualitas hidupnya. Misalnya bagaimana mereka dapat saling berbagi dan memanfaatkan informasi Gerbang Hebat dalam efektifitas pelaksanaan program. Atau bagaimana mereka bekerjasama untuk mencapai tujuan program kewirausahaan. Contoh lainnya adalah UHC (Universal Health Coverage), beasiswa warga miskin, dan pembagian alat kontransepsi gratis. Program-program tersebut secara tidak langsung memberikan akses bagi rumah tangga miskin dalam memenuhi kebutuhan kesehatan, pendidikan. Yang pada akhirnya menjadi salah satu cara peningkatan kapasitas masyarakat pencegahan pertumbuhan penduduk yang tinggi.

Dimensi Jaminan Keamanan, program Gerbang Hebat berupaya mengurangi kerentanan (vulnerability) rumah tangga miskin dengan membentuk program RDRM (Rumah Duka Revolusi Mental) dan program peran serta dan kesetaraan gender dalam pembangunan. Program RDRM (Rumah Duka Revolusi Mental) dibentuk untuk menanggulangi dan menindaklanjuti kasus kekesaran dalam rumah tangga. Program RDRM tersebut bertujuan untuk menindaklanjuti kasus kekerasan pada rumah tangga miskin dengan lebih tanggap dan efisien. Sedangkan program peran serta dan kesetaraan gender dalam pembangunan merupakan program pelatihan bagi kepala keluarga perempuan (single parent) yang rawan ekonomi. Dengan adanya pelatihan tersebut, diharapkan kepala keluarga perempuan mempunyai bekal kemampuan untuk kemudian menjadi modal untuk terus berkembang dalam memenuhi kebutuhan ekonomi.

Dimensi Pemberdayaan Masyarakat, program Gerbang Hebat membentuk beberapa program yang berupaya mengembangkan masyarakat ataupun individu (baik laki-laki maupun perempuan) untuk mengembangkan sumber daya yang ada. Program tersebut di antaranya yaitu Kampung Tematik, WUB (Wirausaha Baru), dan KUBE (Kelompok Usaha Bersama). Pada program Kampung Tematik, masyarakat diharapkan mampu mengembangkan potensi yang ada di desa atau kelurahannya sebagai ciri khas atau identitas desa. Adapun program WUB (Wirausaha Baru) merupakan program berupa pemberdayaan atau pelatihan untuk membentuk masyarakat yang bisa menciptakan usaha baru dengan mengoptimalkan potensi yang ada. Program KUBE (Kelompok Usaha Bersama) yaitu program yang dibentuk untuk mengembangkan usaha yang sudah dimiliki masyarakat, namun terhambat oleh modal. Tujuan pembentukan Program KUBE (Kelompok Usaha Bersama) untuk mengajak masyarakat sekitar bergabung dalam usaha eksisting yang sedang dirintis. Syarat program ini adalah terbentuknya kelompok dengan minimal 10 anggota dengan 1 anggota wajib sudah memiliki usaha. Secara keseluruhan, ketiga program tersebut bertujuan untuk mendorong masyarakat untuk mengembangkan potensi dan sumber daya yang ada di sekitarnya. Hal ini sesuai dengan konsep stimulasi pengentasan kemiskinan melalui penguatan kegiatan ekonomi basis rumah tangga miskin (Gopal \& Malek, 2015)(Nussbaum, 2011)(Narayan, 2005)

Berdasarkan uraian di atas, dapat diketahui bahwa secara garis besar prinsip pelaksanaan program Gerbang Hebat sudah mendekati kesesuaian dengan tujuan 
pengarusutamaan gender. Dilihat dari konteks strategi pengentasan kemiskinan, Gerbang hebat belum sesuai dengan prinsip gender mengingat bahwa sudah ada beberapa program yang bertema gender tetapi belum sepenuhnya menjadi representative pemahaman gender dalam konteks yang lebih riil. Konteks gender di sini lebih ditekankan kepada adanya keterwakilan perempuan sebagai korban dan bukan mengacu pada mediasi kesenjangan relasi kekuasaan antara laki laki dan perempuan dalam konteks individu dan rumah tangga miskin. Walaupun demikian, ada upaya Gerbang hebat untuk menindaklanjuti rekomendasi beberapa penelitian dan best practices dari strategi pengentasan kemiskinan dengan fokus pada penguatan sector ekonomi sebagai cara individu dan rumah tangga miskin keluar dari lingkaran kemiskinan sistemik.

\section{KESIMPULAN}

Berdasarkan penelitian yang telah dilakukan, maka dapat disimpulkan bahwa program Gerbang Hebat dapat dikatakan telah menerapkan pendekatan perencanaan berbasis gender dalam upaya pengentasan kemiskinan di Kota Semarang. Di samping itu, program Gerbang Hebat cukup banyak membentuk kegiatan pemberdayaan yang mendorong masyarakat untuk berkembang, baik dalam mengembangkan usaha (pelatihan) ataupun pengembangan potensi yang ada (Kampung Tematik). Namun, dalam beberapa aspek memang masih dirasa kurang yakni terkait partisipasi yang belum sampai pada tahap pengambilan keputusan serta kontrol pelaksanaan program yang belum melibatkan masyarakat secara aktif.

Ada beberapa catatan untuk ditindaklanjuti dari penelitian ini. Pertama adalah perlunya penguatan pemahaman gender dan penyamaan persepsi tentang gender pada level perencana program. Yaitu untuk kemudian dapat membuat variasi program dalam klaster yang betul-betul mewakili kepentingan / kegiatan individu dan rumah tangga miskin yang harus diakomodir kebutuhannya. Yang kedua terkait pada konteks pemberdayaan masyarakat dan upaya identifikasi fokus kegiatan yang penting dalam strategi pengentasan kemiskinan. Yaitu pada jenis kegiatan ekonomi lokal rumah tangga yang dapat diakses dan dimanfaatkan dalam grup komunitas.

\section{UCAPAN TERIMAKASIH}

Artikel ini merupakan salah satu output penelitian Departemen PWK yang mendapat dukungan dana dari Fakultas Teknik Universitas Diponegoro melalui hibah Penelitian Dasar Tahun 2018.

\section{DAFTAR PUSTAKA}

Bappenas. (2001). Buku 2: Indikator Gender untuk Perencanaan dan Pembangunan.

Chant, S. (2013). Cities through a "gender lens": a golden "urban age" for women in the global South? Environment and Urbanization, 25(1), 9-29. https://doi.org/10.1177/0956247813477809

Chen, M., Vanek, J., Heintz, J., Chen, M., Vanek, J., \& Heintz, J. (2016). Informality , Gender and Poverty : A Global Picture. Economic and Political Weekly, 41(21), 2131-2139.

Fenster, T. (2005). The right to the gendered city: Different formations of belonging in everyday life. Journal of Gender Studies, 14(3), 217-231. https://doi.org/10.1080/09589230500264109

Gopal, P. S., \& Malek, N. M. (2015). Breaking away from the cycle of poverty : The case of Malaysian poor. The Social Science Journal, 52(1), 34-39. https://doi.org/10.1016/j.soscij.2013.10.016

Holmes, R., \& Jones, N. (2010). Rethinking social protection using a gender lens. ODI Worling Paper 320.

Kelkar, G. (2005). Development Effectiveness through Gender Mainstreaming: Gender Equality and Poverty Reduction in South Asia. Economic and Political Weekly, 40(44/45), 4690-4700.

Lillah Haulah. (2018). Kesiapan Pelaksanaan Program Gerbang Hebat Sebagai Upaya Pengentasan Kemiskinan Di Kota Semarang. Diponegoro. 
Moser, C., \& Moser, A. (2005). Gender mainstreaming since Beijing: A review of success and limitations in international institutions. Gender and Development, 13(2), 11-22. https://doi.org/10.1080/13552070512331332283

Narayan, D. (ed). (2002). Empowerment and Poverty Reduction: A Sourcebook. The World Bank, 36(c), 404. https://doi.org/10.1787/9789264194779-en

Narayan, D. (ed). (2005). Measuring Empowerment: Cross Disciplinary Perspectives. Washington DC: The World Bank.

Nato, M. J. (2004). Gender-Responsive Programming for Poverty Reduction. Addies Abeba, Ethiopia.

Nussbaum, M. C. (2011). Creating Capabilities. Cambridge: Harvard University Press.

Pemerintah Kota Semarang. (2018). “ Gerbang Hebat ” Program Pengentasan Kemiskinan dan Pengangguran. Retrieved March 26, 2018, from http://semarangkota.go.id/berita/read/7/berita-kota/1368/gerbanghebat-program-pengentasan-kemiskinan-dan-pengangguran

Porter, D., \& Bank, A. D. (2003). Poverty Reduction Strategy Papers: A New Convergence. World Development, 31(1), 53-69.

Rodenberg, B. (2004). Gender and Poverty Reduction New Conceptual Approaches in.

Rubin, M. M., \& Bartle, J. R. (2005). Integrating gender into government budgets: A new perspective. Public Administration Review, 65(3), 259-272. https://doi.org/10.1111/j.1540-6210.2005.00452.x

Ruddick, S. (1996). Constructing Difference in Public Spaces: Race, Class, and Gender As Interlocking Systems. Urban Geography, 172), 132-151. https://doi.org/10.2747/0272-3638.17.2.132

Sekretariat Negara. Inpres No 9 Tahun 2000 Tentang Pengarusutamaan Gender, 2004 § (2000).

Suryahadi, A., Yumna, A., Raya, U. R., \& Marbun, D. (2010). Review of Government 's Poverty Reduction Strategies, Policies, and Programs in Indonesia Review of Government's Poverty Reduction Strategies , Policies , and Programs in Indonesia. Jakarta.

Swiss Agency for Development and Cooperation. (2003). Gender Equality: a Key for Poverty Alleviation and Sustainable Development.

The World Bank - PNPM Support Facility, Jakarta, I. (2015). 15 Tahun Program Pembangunan Berbasis Masyarakat di Indonesia.

Urban Development Vienna. (2013). Legal Notice: Manual for Gender Mainstreaming In Urban Planning and Urban Development. Urban Development Vienna. Municipal Department 18 (MA18) - Urban Development and Planning.

Women and Development Unit. (2004). Understanding Poverty from a Gender Perspective. Santiago, Chile.

World Bank. (2007). Kaji an Gender dalam Proy ek Pembangunan Berbasis Komunitas : Implikasi bagi PNPM Mandiri. Jakarta. 